\title{
Characterization of recalcitrant material in leachate from an old landfill by spectroscopic methods
}

\author{
Caracterização de material recalcitrante de lixiviado de aterro sanitário \\ antigo por métodos espectroscópicos
}

\author{
Victória Regina Celso Monteiro' \\ Carlos Eduardo Rodrigues Barquilha" \\ Maria Cristina Borba Braga"l'
}

\begin{abstract}
Landfill leachate is a complex aqueous solution whose treatment still demands studies. Leachate biodegradability in a sanitary landfill decreases after years of solid waste degradation in a landfill cell, which renders its treatment by biological processes difficult. Taking this assertion into consideration, the main goal of this study was the determination of some physicochemical characteristics of the leachate from an old landfill located in Curitiba - Brazil. For the characterization, samples were collected in two points, named $\mathrm{P} 1_{1}$ and $\mathrm{P} 1_{2}$. Results were produced by both conventional and spectroscopic methods, such as COD, BOD, DOC, color, and solids; UV-Vis and fluorescence techniques were also used. The results allow pointing out that the landfill has aged and that the leachate presents recalcitrant characteristics, with strong humification. Thus, a physicochemical process can be recommended for the treatment of this leachate. Moreover, the results produced by spectroscopic analyses brought additional information regarding the current stage of degradation of organic matter inside landfill cells. It is worth mentioning that the results produced can be used to subsidize further decisions on adequate leachate treatment and monitoring.
\end{abstract}

Keywords: Leachate; Stabilized organic matter; Humic substances; UV-Vis; Fluorescence spectroscopy.

\section{Resumo}

O lixiviado de aterro sanitário é um efluente com características complexas e que ainda apresenta desafios no seu tratamento. A partir da estabilização da matéria orgânica, que ocorre durante vários anos em um aterro, a biodegradabilidade do lixiviado diminui, dificultando o emprego do tratamento biológico. A partir disso, o objetivo deste trabalho foi identificar as características do lixiviado de um aterro sanitário antigo, localizado em Curitiba - BR, utilizando técnicas convencionais e espectroscópicas. Foram realizadas duas coletas de lixiviado no Aterro Municipal de Curitiba, na entrada do sistema de tratamento do aterro, denominadas $\mathrm{P} 1_{1}$ e $\mathrm{P} 1_{2}$, e foram realizadas análises de $\mathrm{pH}, \mathrm{DQO}, \mathrm{DBO}, \mathrm{COD}$, cor, série de sólidos e análises de espectroscopia de UV-Vis e de fluorescência. A partir das análises realizadas, observou-se que o lixiviado sofreu interferência das taxas de precipitação e pode inferir-se que o aterro estudado está em processo de envelhecimento, com o lixiviado apresentando características recalcitrantes. A matéria orgânica apresentou forte característica húmica, sendo constituída principalmente por substâncias aromáticas como ácidos húmicos e fúlvicos, podendo ser indicada a utilização de tratamento físico-químico para o lixiviado estudado. Além disso, as análises

\footnotetext{
'Parana Federal University, Curitiba, PR, Brazil - victoriarcmonteiro@gmail.com.

"Parana Federal University, Curitiba, PR, Brazil-ce.barquilha@gmail.com.

III Parana Federal University, Curitiba, PR, Brazil- crisbraga@ufpr.br.
} 
espectroscópicas produziram informações adicionais, de maneira mais rápida e com consumo mais baixo de reagentes do que as técnicas convencionais, e são ferramentas promissoras para auxiliar na identificação da etapa de decomposição em que o aterro se encontra, subsidiar o planejamento do tratamento adequado e o monitoramento do lixiviado gerado.

Palavras-Chave: Chorume; Matéria orgânica estabilizada; Substâncias húmicas; Espectroscopias de UVVis e fluorescência.

\section{Introduction}

Landfill leachate is generated from the natural moisture of solid wastes, combined with liquids produced by waste decomposition and rainwater infiltrated inside landfill cells. Chemical and biochemical processes produce dark-colored wastewater with an unpleasant odor, high concentration of organic matter, and variable composition (ABNT, 1992; LANGE, AMARAL, 2009; BRAGA et al., 2012).

Dissolved organic matter, inorganic macro components, heavy metals, and organic xenobiotic compounds are the four main groups of pollutants found in leachate (CHRISTENSEN et al, 1994; KJELDSEN et al, 2002). Many factors interfere in the leachate composition, for instance, waste composition, depth of cells, moisture content, amount of rainfall, compaction of disposed waste, toxicity of co-disposed waste, however, the age of the landfill can be highlighted (EI-FADEL et al., 2002). In general, the majority of contaminants present in the leachate tend to reach their highest concentrations in the first months after being landfilled, which is, in particular, the case of biodegradable organic matter. However, over a period of several years, a continuous and steady reduction of concentrations follows, and is dependent on the stage of solid waste degradation inside the landfill cells. Other contaminants, such as non-biodegradable organics and iron, tend to persist in the leachate for many years (FARQUHAR, 1989).

According to Rodrigues et al. (2009) and Lange and Amaral (2009), the low biodegradability of leachate from old landfills can be attributed to the presence of recalcitrant substances, which are high molecular weight compounds that resist biodegradation and tend to persist and accumulate in the environment, such as humic, fulvic and tannic acids. The low biodegradability of some substances, such as refractory 
organic matter, impairs the treatment of leachate by biological processes. Thus, to improve the efficiency of the system, it would require the application of physicochemical processes or advanced treatments.

Several parameters have been used to characterize the content of dissolved organic matter in the leachate. For instance, TOC (total organic carbon), COD (chemical oxygen demand), and BOD (biochemical oxygen demand), whereas the determination of humic or recalcitrant substances can be carried out by the analysis of DOC (dissolved organic carbon) (APHA, 1999; KJELDSEN et al., 2002). According to some authors, the composition of dissolved organic matter in landfill leachate can also be determined by other methods such as infrared spectroscopy (IR), Fourier-transform infrared spectroscopy (FTIR), nuclear magnetic resonance (NMR), mass spectroscopy, among others (Kang et al., 2002; Xiaoli et al., 2013; Peixoto et al. 2018). These techniques can be used to characterize landfill leachate and thus identify humic substances by providing the chemical structure of organic matter, the identification of functional groups, structural properties, and molecular mass, among others. The determination of these characteristics enables identifying the aromaticity, the recalcitrant characteristics, the molecular mass distribution, as well as the degree of stabilization of the landfill. However, according to Sheng et al. (2007), although some advanced techniques have provided a considerable amount of information on the structure and functional properties of humic acids, many of them are both expensive, timeconsuming and require complex instruments.

According to Sheng et al. (2007), ultraviolet-visible (UV-Vis) spectroscopy is a method normally used to determine the aromaticity of humic substances. Due to its strong linear relationship with DOC, this technique is commonly used to determine the absorbance at the wavelength of $254 \mathrm{~nm}$ (LEE et al., 1981 apud ZOUBOULIS et al., 2004). Humic substances usually present strong absorption in the UV-Vis regions due to the presence of aromatic and organic matter. Therefore, absorbance at wavelengths of 254 $\mathrm{nm}$ and $285 \mathrm{~nm}$ are commonly used to correlate the carbon-carbon double bonds or 
hybridized carbon sp² in aromatic substances (WESTERHOFF, ANNING, 2000; REN et al., 2018).

Fluorescence spectroscopy is a technique also used to determine and qualitatively characterize dissolved organic matter in natural waters, and in particular, more recently, applied to characterize landfill leachate (HUO et al., 2009; YUNUS et al., 2011; XIE, GUAN, 2015). Two types of fluorescence have been studied, the fluorescence of humic substances and the fluorescence of proteins. The so-called fluorescence of proteins comes either from isolated aromatic amino acids, such as tyrosine and tryptophan, or from proteins in which these amino acids take part. These substances are denominated fluorophore and emit signals at certain wavelengths, designated as bands (COBLE, 1996; CARSTEA, 2012), as sown in Table 1. 
Table 1 - Bands of fluorescence spectroscopy, molecular structure of tyrosine and tryptophan, and hypothetic molecular structure of humic and fulvic acids

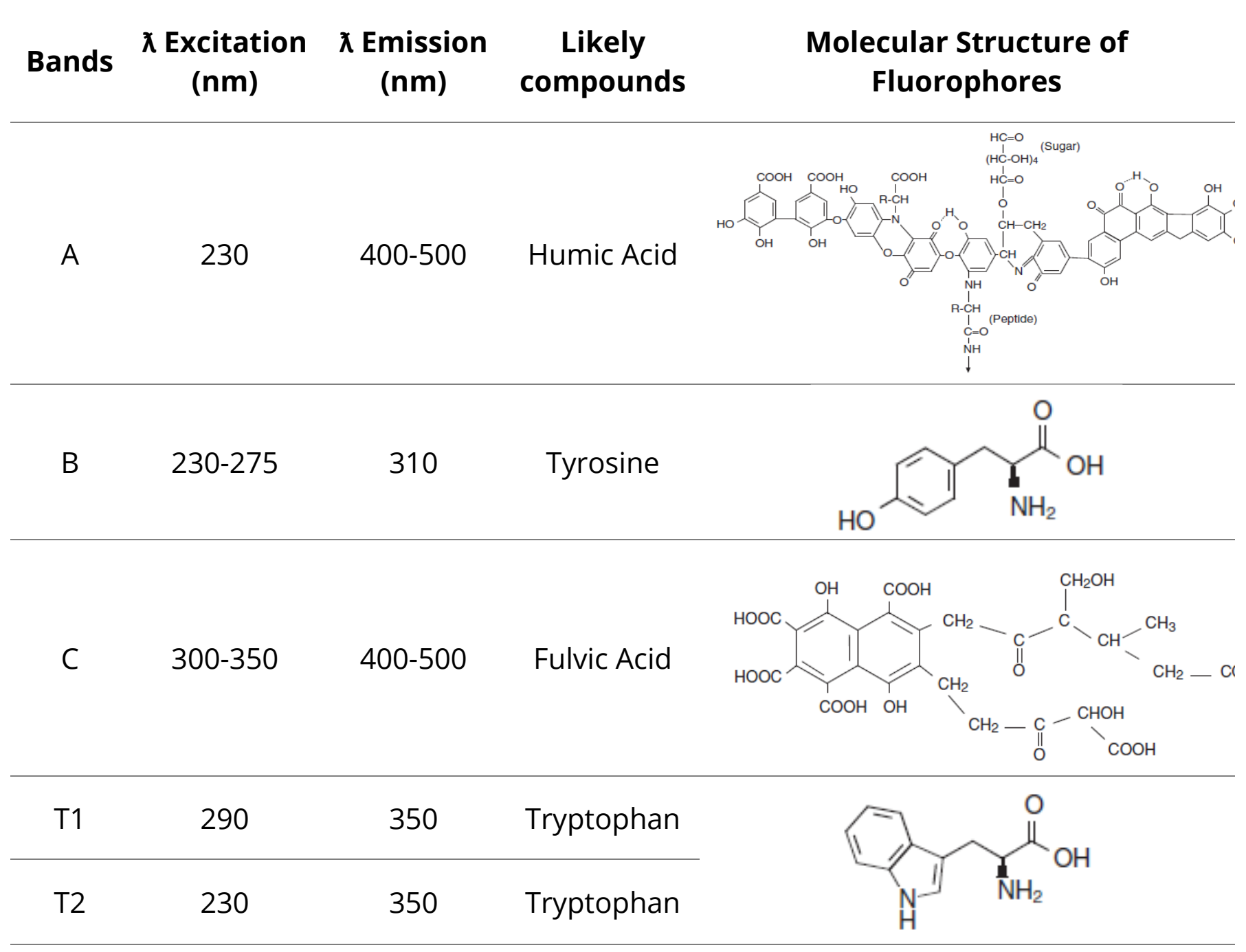

Source: adapted from Coble (1996); Hudson et al. (2007); Carstea (2012).

The ultraviolet-visible absorption spectrum of a given molecule can also be produced and used to assist in the identification of substances (SKOOG et al., 2005), for instance, organic matter. This technique provides the quantity of absorbed light as a function of the molecular structure of the chemical under investigation. Double carbon bonds absorb energy in the range between $250 \mathrm{~nm}$ and $280 \mathrm{~nm}$ (WESTERHOFF, ANNING, 2000). The calculation of indices is another form to express results produced by visible ultraviolet and fluorescence spectroscopies. Absorption indices, according to $\mathrm{Li}$ and Hur (2017), are defined as the ratio of two different wavelengths absorption 
coefficients and have been used to examine sources and composition of dissolved organic matter.

The A285 and SUVA indices, for instance, are respectively presented as the ratio of the UV-Vis absorbance at the wavelength of $285 \mathrm{~nm}$ and $254 \mathrm{~nm}$ to DOC concentration. The first index indicates whether the compounds are predominantly refractory pedogenic or aliphatic aquagenic, whereas the latter relates the aromatic content of organic matter with the concentration of organic carbon. The A300/A400 and A250/A365 indices are respectively expressed as ratios of UV-Vis absorbances negatively correlated to the degree of humification and the molecular weight of the compounds (ROSTAN, CELLOT, 1995;WESTERHOFF, ANNING, 2000; CLARET et al., 2003; PEURAVUORI, PIHLAJA, 1997). Two other indices can be calculated using the fluorescence intensities, the fluorescence ratio (FR), which indicates the source of organic matter, as pedogenic or anthropic allochthonous, and the humification index (HIX), which refers to the degree of humification of organic matter (WESTERHOFF, ANNING, 2000; HUGUET et al., 2009).

According to Baettker et al. (2020), UV-Vis and fluorescence spectroscopic techniques can be used as fast and sensitive measures for the determination of the composition of dissolved organic matter in leachate samples. The association made possible by the results of $C O D$ and $B O D$ analyzes provides a more detailed characterization of the leachate, which facilitates the choice and selection of an adequate method of treatment. In addition, these authors considered the analysis of dissolved organic matter by spectroscopic techniques more economical than those resulted from conventional physicochemical analysis.

Therefore, ultraviolet and fluorescence spectroscopies can be used in conjunction with conventional methods to provide complete information on the recalcitrant organic matter present in leachate from stabilized landfills. Thus, based on the background information presented, the objective of this study was to identify the characteristics of organic matter in the leachate from an old landfill, located in Curitiba - BR, using conventional physicochemical parameters and spectroscopic techniques. 


\section{Material and Methods}

The area adopted for the development of this study was a closed landfill located in the south region of Curitiba - Brazil, whose geographical coordinates are $25^{\circ} 37^{\prime} 29^{\prime \prime} \mathrm{S}$ and $49^{\circ} 20^{\prime} 66^{\prime \prime}$ W. This landfill was launched in 1989, operated over a period of 21 years, and received approximately 12 million tons of household solid waste from Curitiba and other 21 cities of the Metropolitan Area.

The raw leachate was collected in two different points, named $\mathrm{P} 1_{1}$ and $\mathrm{P} 1_{2}$, the first in April and the latter in July of 2019. According to official data, in April, an average rainfall of $50.2 \mathrm{~mm}$ accumulated over a period of 3 days prior to the first sampling collection, whereas only $12 \mathrm{~mm}$ were registered during the whole month of July (CEMADEN, 2020; ÁGUASPARANÁ, 2020).

The parameters and the methods used for leachate characterization are presented in Table 2. All tests were performed at the Laboratory of Environmental Engineering Professor Francisco Borsari Netto of the Department of Hydraulics and Sanitation, Parana Federal University (UFPR).

In order to carry out the analyses of DOC, UV-Vis, and fluorescence spectroscopy, samples were filtered through cellulose acetate membranes $(0.45 \mu \mathrm{m})$ and stored in glass bottles previously calcined at $550^{\circ} \mathrm{C}$. For the analyses of DOC, samples were diluted in pure water until the reading limit of the equipment was reached, acidified with $\mathrm{H}_{2} \mathrm{SO}_{4}$ (P.A.) to $\mathrm{pH}$ lower than 2, and sprayed with gaseous nitrogen to eliminate inorganic carbon eventually present in the samples.

The fluorescence and ultraviolet spectroscopy analyses were carried out in the Laboratory of Environmental Chemistry of the Department of Chemistry and Biology at Federal University of Technology - Paraná (UTFPR). To circumvent high fluorescence

intensities presented by leachate, and also to correct the inner filter effects, the samples were diluted in pure water, 100 times for $\mathrm{P} 1_{1}$ and 200 times for $\mathrm{P} 1_{2}(\mathrm{OHNO}$, 2002; BAKER, CURRY, 2004). 
Table 2 - Parameters and methodologies used for leachate analysis

\begin{tabular}{|c|c|c|}
\hline $\begin{array}{l}\text { Physical-Chemical } \\
\text { Parameters }\end{array}$ & Unity & Metodology and/or Equipament Used \\
\hline $\mathrm{pH}$ & - & Potenciometric, pHmeteter QX 1500 Plus - Qualxtron \\
\hline \multirow{2}{*}{ Apparent Color } & \multirow{2}{*}{$\begin{array}{l}\text { Color } \\
\text { Units } \\
\text { (CU) }\end{array}$} & 2120 B Method, APHA, 1999 \\
\hline & & Nessler Quanti 200 Colorimeter \\
\hline $\begin{array}{l}\text { Chemical Oxygen Demand } \\
\text { (COD) }\end{array}$ & $\mathrm{mgL}^{-1}$ & Reflux Closed Method - APHA, 1999 \\
\hline Dissolved COD & $\mathrm{mgL}^{-1}$ & Reflux Closed Method - APHA, 1999 \\
\hline $\begin{array}{l}\text { Biochemical Oxygen Demand } \\
\text { (BOD) }\end{array}$ & $\mathrm{mgL}^{-1}$ & Manometric Method - APHA, 1999 \\
\hline \multirow{2}{*}{$\begin{array}{l}\text { Dissolved Organic Carbon } \\
\text { (DOC) }\end{array}$} & \multirow{2}{*}{$\mathrm{mgL}^{-1}$} & Combustion Method - APHA, 1999 \\
\hline & & TOC-VCP 5000-A SHIMADZU \\
\hline Total Solids (TS) & $\mathrm{mgL}^{-1}$ & Gravimetric Method - APHA, 1999 \\
\hline Total Fixes Solids (TFS) & $\mathrm{mgL}^{-1}$ & Gravimetric Method - APHA, 1999 \\
\hline Total Volatile Solids (TVS) & $\mathrm{mgL}^{-1}$ & Gravimetric Method - APHA, 1999 \\
\hline Total Suspended Solids (TSS) & $\mathrm{mgL}^{-1}$ & Gravimetric Method - APHA, 1999 \\
\hline Total Dissolved Solids (TDS) & $\mathrm{mgL}^{-1}$ & Gravimetric Method - APHA, 1999 \\
\hline
\end{tabular}

A range of excitation wavelengths ( $\lambda$ ) from $200 \mathrm{~nm}$ to $600 \mathrm{~nm}$, with a 5 -nanometer interval, and emission wavelengths from $200 \mathrm{~nm}$ to $610 \mathrm{~nm}$, with a 2-nanometer interval, were used to capture the fluorescence spectra. The scanning speed used was $8000 \mathrm{~nm} \mathrm{~min}{ }^{-1}$. A Cary Eclipse fluorimeter (Varian Inc.), with a multifaceted quartz cuvette, an optical path of $1 \mathrm{~cm}$, and pure water as blank, was used to carry out these analyses.

Absorbances between wavelengths of $200 \mathrm{~nm}$ and $600 \mathrm{~nm}$ were also measured, with a 1-nanometer interval. The scanning speed used was $4800 \mathrm{~nm} \mathrm{~min}{ }^{-1}$. The resulting spectrum allowed evaluating the absorbance at a wavelength of $254 \mathrm{~nm}$. This procedure was in accordance with method 5910 B, as presented in the Standard 
Methods of Examination of Water and Wastewater (APHA, 1999). Taking into consideration the dilutions used, the normalization of data of the excitation and emission matrices (MEE) as well as the calculation of the fluorescence and ultraviolet indices were based on the results of the UV-Visible absorbances, dissolved organic carbon concentrations, and fluorescence intensities. These procedures were performed using the Python Fluorescence Excitation-Emission Matrix Code (FEEMC 2.0), developed by Kozak et al. (2017). A Cary 50 - UV-Visible spectrophotometer (Varian Inc.), with a multifaceted quartz cuvette, an optical path of $1 \mathrm{~cm}$, and pure water as blank, was used to carry out the analyses of ultraviolet-visible spectroscopy.

\section{Results and Discussion}

Firstly, it is important to mention that the similarity of results produced from both collections, P11 and P12 (Table 3), led to the consideration that the rainfall event registered during 3 days before the sampling collection in P11 did not affect the concentration of pollutants.

The dark color observed, with high values of apparent color, between 3,000 CU and 4,000 CU, may be associated with the presence of humic substances in the leachate of this old landfill (TONG et al., 2015). However, these values were lower than those reported by Lima et al. (2017), who found values between 4,977 mg Pt Co L-1 and 8,197 mg Pt CoL ${ }^{-1}$. On the other hand, Baettker et al. (2020) investigated leachate from a landfill operating over a period of 10 years, also located in Curitiba's Metropolitan Area - Brazil, and observed color values close to those registered by this research, which varied between 2,250 CU and 4,500 CU. 
Table 3 - Characterization of leachate

\begin{tabular}{lcc}
\hline Evaluated Parameters & $\mathbf{P} \mathbf{1}_{\mathbf{1}}$ & $\mathbf{P 1}_{\mathbf{2}}$ \\
\hline $\mathrm{pH}$ & $9.2 \pm 0.03$ & $9.2 \pm 0.02$ \\
Apparent Color $(\mathrm{CU})^{*}$ & 3,750 & 3,000 \\
COD $\left(\mathrm{mg} \cdot \mathrm{L}^{-1}\right)$ & $948.9 \pm 63.1$ & $1,315.0 \pm 103.8$ \\
Dissolved COD $\left(\mathrm{mg} \cdot \mathrm{L}^{-1}\right)$ & $810.0 \pm 68.4$ & $1,231.7 \pm 169.2$ \\
BOD $\left(\mathrm{mg} \cdot \mathrm{L}^{-1}\right)$ & $150.0 \pm 0.0$ & $160.0 \pm 0.0$ \\
DOC $\left(\mathrm{mg} \cdot \mathrm{L}^{-1}\right)$ & $401.6 \pm 5.2$ & $487.4 \pm 5.0$ \\
TS $\left(\mathrm{mg} \cdot \mathrm{L}^{-1}\right)$ & $3,717.3 \pm 83.4$ & $5,313.3 \pm 120.7$ \\
TFS $\left(\mathrm{mg} \cdot \mathrm{L}^{-1}\right)$ & $2,748.0 \pm 114.0$ & $4,018.7 \pm 206.2$ \\
TVS $\left(\mathrm{mg} \cdot \mathrm{L}^{-1}\right)$ & $969.3 \pm 30.0$ & $1,294.7 \pm 85.5$ \\
TDS $\left(\mathrm{mg} \cdot \mathrm{L}^{-1}\right)$ & $3,622.0 \pm 93.6$ & $5,291.2 \pm 113.7$ \\
TSS $\left(\mathrm{mg} \cdot \mathrm{L}^{-1}\right)$ & $95.3 \pm 10.3$ & $22.2 \pm 7.1$ \\
BOD/COD & 0.16 & 0.12 \\
COD/BOD & 6.32 & 8.21 \\
Absorbance at $254 \mathrm{~nm}$ & 7.44 & 15.26 \\
\hline
\end{tabular}

Notes: mean values \pm standard deviation.

* not evaluated in triplicate - it was determined by visual observation (method 2120 B; APHA, 1999), it was.

Comparing the results presented in Table 3 with those produced by other authors, who studied the same landfill, it can be pointed out that, in fact, the values of the physicochemical parameters varied over time. In previous studies, the values varied from 8.3 to 8.6 for $\mathrm{pH}^{2} ; 2,900 \mathrm{mg} \mathrm{L}^{-1} ; 9,400 \mathrm{mg} \mathrm{L}^{-1}$ for COD; $500 \mathrm{mg} \mathrm{L}^{-1}$ to 2,300 $\mathrm{mg} \mathrm{L}^{-1}$ for DOC, whereas an average value of $720 \mathrm{mg} \mathrm{L}^{-1}$ was registered for BOD (PACHECO, ZAMORA, 2004; MORAIS, ZAMORA, 2005; ROCHA, 2011; DIAS, 2013; FERREIRA, 2014).

It is worth mentioning that lower organic matter concentrations and higher $\mathrm{pH}$ values are typical characteristics of aging landfills. In particular, the values of $\mathrm{pH}$ can be related to increased concentrations of ammonium nitrogen over time (data not shown). 
The aging process of the landfill is due to the methanogenic phase of solid waste degradation. In this phase, the acids previously produced are converted into methane and carbon dioxide, and the $\mathrm{pH}$ increases. In a subsequent stage, in the stable methanogenic phase, the DOC concentration is reduced, whereas the $\mathrm{pH}$ increases until a stable condition is reached (KJELDSEN et al., 2002).

Similar values of COD (810.0 $\mathrm{mg} \mathrm{L}^{-1}$ and $\left.1,231.7 \mathrm{mg} \mathrm{L}^{-1}\right)$ and total COD $(948.9 \mathrm{mg}$ $\mathrm{L}^{-1}$ e $1,315.0 \mathrm{mg} \mathrm{L}^{-1}$ ) indicate that most of the organic matter was dissolved. These results are corroborated by Kjeldsen et al. (2002), who stress that landfill leachate can usually contain high levels of dissolved organic matter.

A high concentration of dissolved substances can also be observed when the concentrations of dissolved solids (3,622 $\mathrm{mg} \mathrm{L}^{-1}$ for $\mathrm{P} 1_{1}$ and 5,291.2 $\mathrm{mg} \mathrm{L}^{-1}$ for $\left.\mathrm{P} 1_{2}\right)$ are compared with low concentrations of suspended solids (95.3 $\mathrm{mg} \mathrm{L}^{-1}$ and $22.0 \mathrm{mg} \mathrm{L}^{-1}$, respectively). This characteristic was also observed by Pedro-Cedillo et al. (2015). These authors observed that the fraction of dissolved solids reached $98 \%$ of the total solids, which were also related to high values of color for the studied leachate.

The values for the biodegradability factor of the leachate, i.e., the ratio of BOD to COD, were 0.16 and 0.12 for $\mathrm{P} 1_{1}$ and $\mathrm{P} 1_{2}$, respectively. According to Gomes et al. (2006), there are three categories in which the leachate can be classified i) young $(>0.5)$, ii) intermediate $(0.5-0.1)$, and iii) old $(<0.1)$. Thus, these results allow the classification of the leachate as stabilized. These values were similar to those obtained by Labanowski et al. (2010) of 0.18, Zouboulis et al. (2004) and Pedro-Cedillo et al. (2015) of 0.08, who also studied leachate from old landfills.

The inverse ratio, given by $C O D / B O D$, can also be used to evaluate the biodegradability of wastewater, and it is considered high when greater than 3.5 or 4.0 (VON SPERLING, 2005). From the calculated values of 6.32 and 8.21 , it can be pointed out that the inert or non-biodegradable fraction is predominant. Thus, it can be suggested that a stage of physicochemical treatment could be added to the wastewater system in operation at the landfill area. 
The biodegradability of the leachate can also be evaluated through the concentrations of total fixed solids (TFS) and total volatile solids (TVS). The TVS concentration was about one-third of the TFS concentration for both sampling collections, which indicates that the largest fraction of solids is present as an insoluble component. Therefore, indicating that the fixed fraction is non-biodegradable.

The spectroscopic analysis used to determine the absorbance at $254 \mathrm{~nm}$, in turn, indicates the presence of organic constituents that absorb ultraviolet-visible radiation. On one hand, absorbance at this wavelength has been used to determine the humic substances through the correlation with the concentration of DOC (ZOUBOULIS et al., 2004). On the other hand, results produced at this wavelength have been used to evaluate the efficiency of treatment of stabilized landfill leachate (OLOIBIRI et al., 2015), as well as to indicate the presence of aromatic organic matter (LIMA et al., 2017).

As presented in Table 3, values of 7.44 for $\mathrm{P} 1_{1}$ and 15.26 for $\mathrm{P} 1_{2}$ were observed for the absorbance at $254 \mathrm{~nm}$, which suggests a strong presence of aromatic substances in the leachate from the second sampling collection. Lima et al. (2017) reported absorbance values of 14.0 and 25.0 at $254 \mathrm{~nm}$ for landfills operating over periods of 27 years and 35 years, respectively. Therefore, the value determined for $\mathrm{P} 1_{2}$, for a landfill launched in 1989, can be considered similar to the 35-year old landfill studied by Lima et al. (2017). On the other hand, the value obtained for $P 1_{1}$ is similar to that obtained by Gu et al. (2018), who obtained an absorbance value of 6.17 at $254 \mathrm{~nm}$, with a BOD/COD ratio of 0.01 .

Absorbances for the UV-Vis spectra are presented in Figure 1. The determination of the UV-Vis spectrum was carried out by scanning between the wavelengths of 200 $\mathrm{nm}$ and $600 \mathrm{~nm}$ for both leachate collections, as well as for pure water samples used as blank. Strong absorbances were observed in the range between $200 \mathrm{~nm}$ and $300 \mathrm{~nm}$. The observed values were higher for $\mathrm{P}_{2}$, which indicates the presence of aromatic structures. According to Pacheco and Zamora (2004), such structures strongly absorb UV-visible radiation in the region between $250 \mathrm{~nm}$ and $300 \mathrm{~nm}$. 
Figure 1 - Ultraviolet-visible spectra

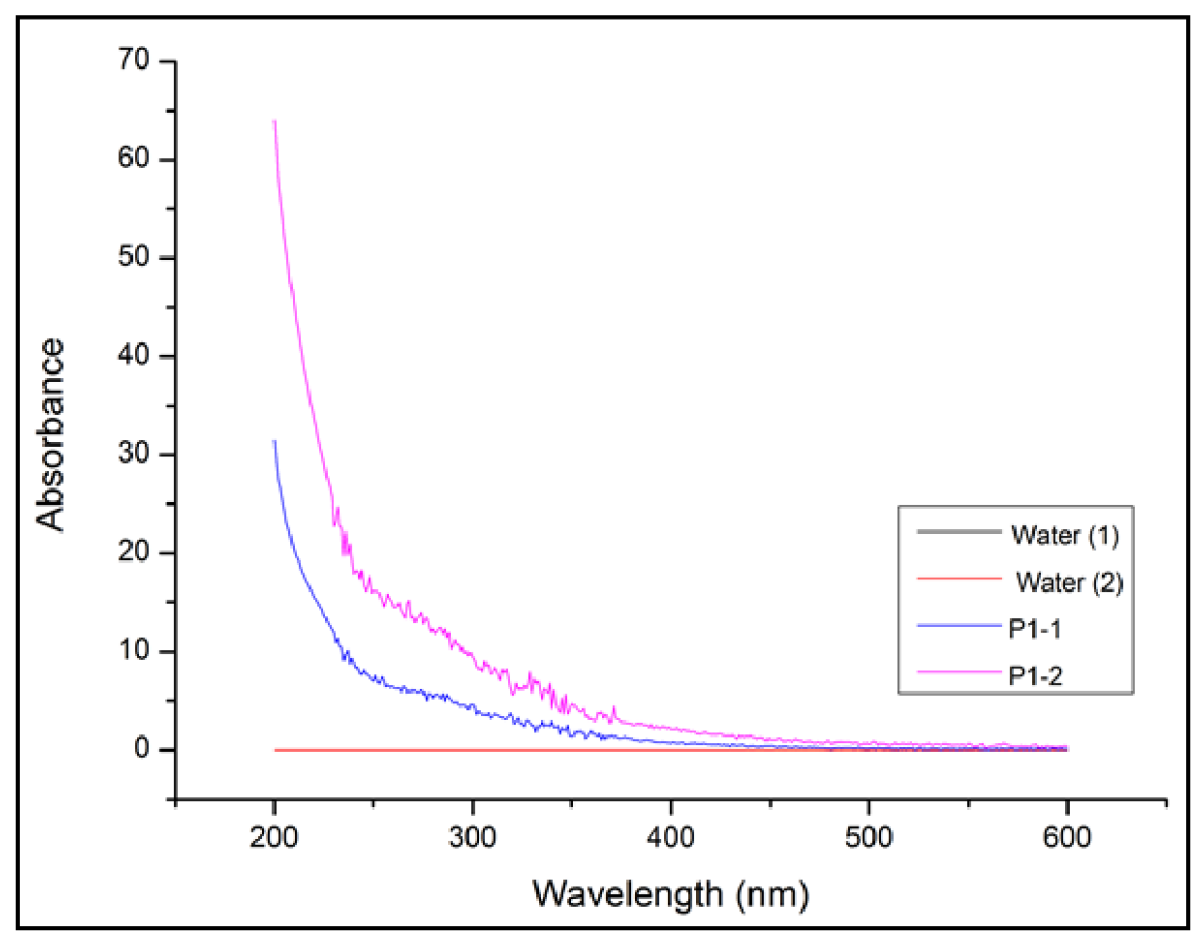

Note: a) absorbance values were corrected according to the dilutions of samples. b) sampling collections $1\left(\mathrm{P} 1_{1}\right)$ and $2\left(\mathrm{P} 1_{2}\right)$.

Fluorescence spectroscopy, excitation and emission matrices (MEE) for P1 1 and $\mathrm{P} 1_{2}$ are shown in Figure 2. Bands A and C, referred to as humic and fulvic acids, respectively, were the most intense for both samples. These results indicate the prevalence of substances considered recalcitrant and aromatic. Bands T1 and T2, referred to as tyrosine, and band $B$, referred to as tryptophan, represent the most labile substances and presented lesser intensity than the humic bands. These results indicate that the main characteristics of the leachate studied are related to refractory organic matter. 
Figure 2 - Excitation and emission matrices (MEE) of fluorescence

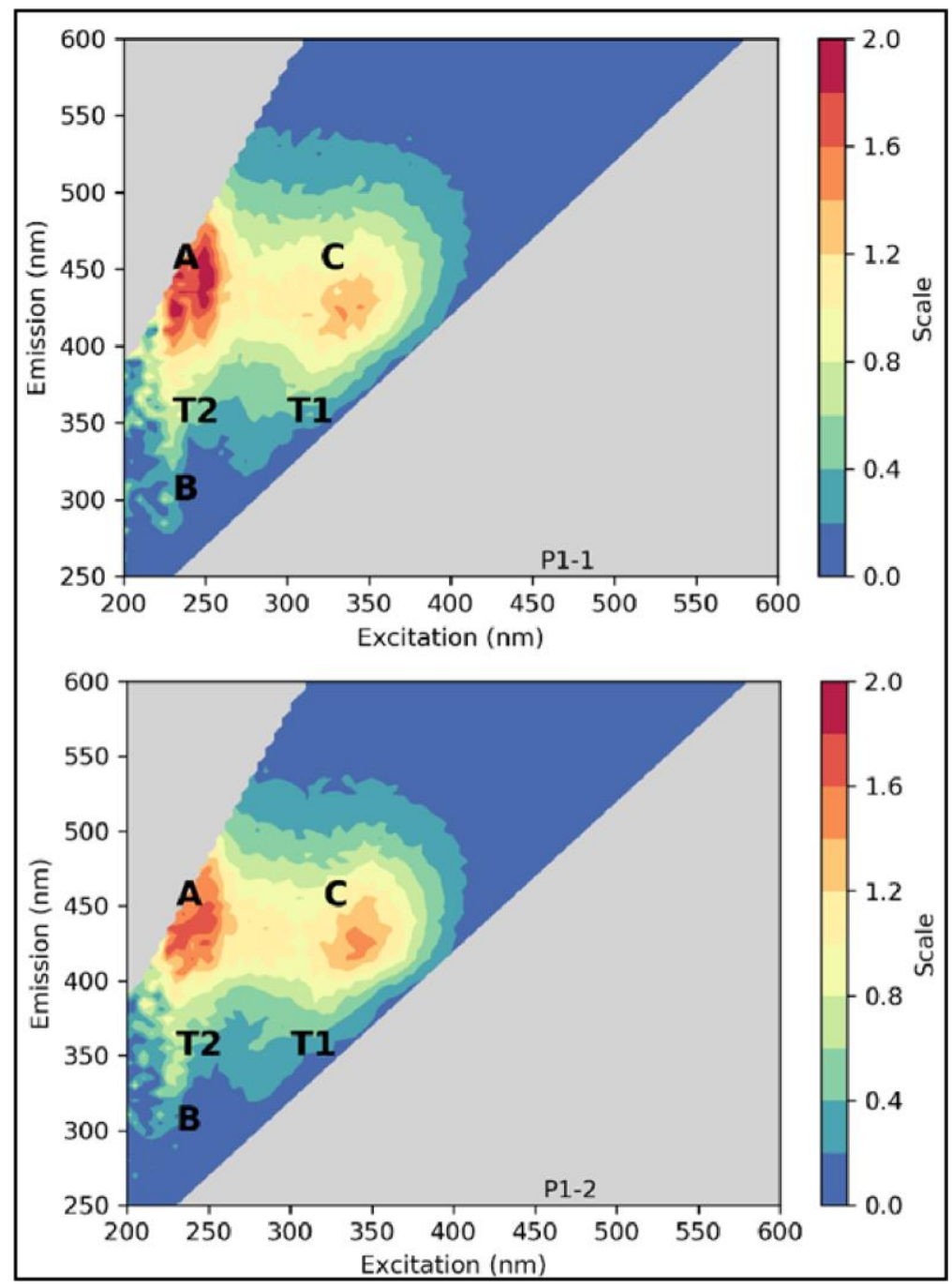

Note: sampling collections $1\left(\mathrm{P} 1_{1}\right)$ and $2\left(\mathrm{P} 1_{2}\right)$.

These results were corroborated by those produced by Xie and Guan (2015), who studied leachate from 3 different landfills, 4-year old, 5-year old, and 6-year old. These authors observed that the characteristics of the spectra varied according to the age of the landfill, i.e., the older the landfill, the lower the intensity of the protein bands, and the greater the intensity of the fulvic acid bands. In the present study, as the landfill is older (31 years), it was observed that the intensity of the labile bands was even lower than that of the recalcitrant bands.

Data used to build Figure 2 are shown in Table 4. Regarding P12, these values show a slight decrease in peak $A$ and an increase in peak $C$, which may be related to a higher concentration of fulvic acid. Peaks of labile substances $(B, T 1$, and $T 2)$ were less 
intense and did not present considerable variation between the two sampling collections. It is noteworthy that, despite similarities between humic and fulvic acids, the mass spectrometry technique can be used to evaluate the presence of humic substances that are derived from lignin, which resists microbial degradation (XIAOLI et al., (2008).

Table 4 - Peaks of intensity of fluorescence for bands A, B, C, T1 and T2 obtained from MEES

\begin{tabular}{lccccc}
\hline Peaks & A & B & C & T1 & T2 \\
\hline $\mathrm{P} 1_{1}$ & 1.96 & 0.33 & 1.49 & 0.43 & 0.86 \\
$\mathrm{P} 1_{2}$ & 1.78 & 0.29 & 1.52 & 0.40 & 0.72 \\
\hline
\end{tabular}

The indices calculated from the absorbance and fluorescence spectroscopy are presented in Table 5. According to Rostan and Cellot (1995), values of A285 (ratio of absorbance at $285 \mathrm{~nm}$ to DOC) near $20 \mathrm{~g} \mathrm{~L}^{-1}$ allow the consideration that the organic matter is essentially composed of refractory organic carbon or fulvic compounds. Thus, the values $14 \mathrm{~g} \mathrm{~L}^{-1}$ for $\mathrm{P} 1_{1}$, and $24 \mathrm{~g} \mathrm{~L}^{-1}$, for $\mathrm{P} 1_{2}$ obtained by this study indicate a more refractory characteristic or stronger presence of fulvic acid for $\mathrm{P} 1_{2}$, whereas $\mathrm{P} 1_{1}$ presented an intermediate characteristic, which positioned it between refractory and aliphatic compounds.

The parameter SUVA (ratio of absorbance at $254 \mathrm{~nm}$ to DOC), in turn, indicates that values above $2.0 \mathrm{mg} \mathrm{m}^{-1}$ are related to structures predominantly aromatic (WEISHAAR et al., 2003). Thus, as values of $1.86 \mathrm{mg} \mathrm{m}^{-1}$ for $\mathrm{P} 1_{1}$ and $3.13 \mathrm{mg} \mathrm{m}^{-1}$ for $\mathrm{P} 1_{2}$ were obtained, it can be pointed out that the latter presented a more aromatic characteristic than P1 1 . Other authors, who studied another landfill in Curitiba's Metropolitan Area observed values of SUVA varying from $0.46 \mathrm{mg} \mathrm{m}^{-1}$ and $2.64 \mathrm{mg} \mathrm{m}^{-1}$. These results highlight the strong variation of this wastewater (BAETTKER et al., 2020).

According to some authors, the A300/A400 index is negatively related to the degree of humification, since values between 2.67 and 3.10 indicate humic acid, 
whereas values between 5.14 and 7.03 indicate fulvic acid (CLARET et al., 2003); LI, HUR, 2017). Thus, the lower values obtained for $P 1_{2}$ indicate a more humic characteristic than that of $\mathrm{P} 1_{1}$ or, on the other hand, a more prominent presence of humic acid in $\mathrm{P} 1_{2}$ and fulvic acid in $\mathrm{P} 1_{1}$.

Table 5 - Absorbance and fluorescence spectroscopy indices

\begin{tabular}{ccccccc}
\hline Indexes & A285 (g.: $\left.\mathrm{L}^{-1}\right)$ & SUVA $\left(\mathrm{mg}^{-1} \mathbf{m}^{-1}\right)$ & A300/A400 & A250/A365 & FR & HIX \\
\hline $\mathrm{P} 1_{1}$ & 14.34 & 1.86 & 6.58 & 6.66 & 1.98 & 10.83 \\
$\mathrm{P} 1_{2}$ & 24.16 & 3.13 & 4.51 & 4.17 & 2.38 & 10.64 \\
\hline
\end{tabular}

Note: sampling collections $1\left(\mathrm{P} 1_{1}\right)$ and $2\left(\mathrm{P} 1_{2}\right)$.

Another index considered for the evaluation of the leachate used for the development of this study, the A250/A365 index, presented a negative correlation between molecular weight and aromaticity of the molecule (PEURAVUORI, PIHLAJA, 1997; LI HUR, 2017). It was observed that the molecular weight and aromaticity were higher for $\mathrm{P} 1_{2}$, which presented a lower index value when compared with $\mathrm{P} 1_{1}$. Baettker et al. (2020) found values of A250/A365, which varied between 3.30 and 5.38. These values are similar to those found in this study.

The Fluorescence Ratio (FR) (Table 5) presented values below 1.5, which indicate pedogenic allochthonous organic matter, whereas values above 1.8 indicate autochthonous or anthropic allochthonous (WESTERHOFF, ANNING, 2000; LEITHOLD, 2017). Therefore, the results produced, above 1.8 , indicate that the organic matter is related to the anthropogenic allochthonous source, that is, it comes from human activities such as the leachate derived from household solid waste, and thus, it is not from natural origin.

Finally, the humification index $(\mathrm{HIX})$ indicates the degree of humification of a sample, where values below 4 indicate autochthonous organic matter; values between 4 and 6 suggest a low humic characteristic; values between 6 and 10 are related to strong humic characteristic, and values above 16 indicate a very strong humic characteristic from pedogenic contribution (HUGUET et al., 2009). Since both points 
analyzed presented values of HIX close to 10, this indicates that the samples presented strong humic characteristics. Gu et al. (2018), who studied leachate generated in China with a BOD/COD ratio of 0.01 , obtained a HIX value of 8.96 . This value was lower than that observed for the leachate used in this study. However, as the value is in the same range, it has been considered to present a strong degree of humification.

\section{Conclusion}

The spectroscopic analyses and the calculated indices indicated the presence of aromatic substances, high molecular weight substances of anthropic origin. The organic matter presented strong humic characteristics, being composed mainly of humic and fulvic acids, considered recalcitrant substances.

Therefore, the results allow suggesting the adoption of alternatives of physicochemical treatment for this leachate, such as either coagulation/sedimentation or adsorption processes or even membrane filtration. These suggestions are based on the fact that biological processes may have not provided adequate results in terms of organic matter removal/reduction, which can be related to the low biodegradability observed for the studied leachate.

The spectroscopic analyses corroborated the results obtained by physicochemical analyses and also brought additional information on faster and low reagent consumption when compared with conventional techniques. Such methods present the potential to become useful tools to assist in identifying the stage of organic matter degradation in which the landfill fits in. The results produced by the use of these techniques can subsidize decision making in terms of choosing an adequate treatment system. They can also assist in the monitoring of the leachate characteristics aiming at the disposal into receiving water bodies even after long periods from the landfill closure.

The leachate generated presented recalcitrant characteristics, with a low concentration of biodegradable organic matter, high concentration of total fixed solids, 
high $\mathrm{pH}$, and $\mathrm{BOD} / \mathrm{COD}$ ratio close to 0.1 , conditions consistent with leachate from an old and stabilized landfill. Thus, it can be concluded that the studied landfill has aged, and it is likely between methanogenic and stable methanogenic phases.

\section{Acknowledgments}

The authors gratefully acknowledge the support provided by the Coordination for the Improvement of Higher Education Personnel (Coordenação de Aperfeiçoamento de Pessoal de Nível Superior - CAPES), Water Resources and Environmental Engineering Post-Graduate Program (PPGERHA-UFPR) and the Laboratory of Environmental Chemistry of the Chemistry and Biology Department at UTFPR.

\section{References}

AGUASPARANÁ [Internet]. Curitiba: Governo do Estado do Paraná. Secretaria do Desenvolvimento Sustentável e do Turismo. Sistema de Informações Hidrológicas, Pluviometria. 2020. Available from: http://www.aguasparana.pr.gov.br/pagina264.html.

ASSOCIAÇÃO BRASILEIRA DE NORMAS TÉCNICAS -ABNT. NBR 8419 - Apresentação de projetos de aterros sanitários de resíduos sólidos urbanos. ABNT, 1992. Rio de Janeiro - RJ.

APHA. Standard Methods for the Examination of Water and Wastewater, 1999. Washington: APHA - American Public Health Association, $21^{\circ}$ Edição.

BAETTKER, E. C.; KOZAK, C.; KNAPIK, H. G.; AISSE, M. M. Applicability of conventional and non-conventional parameters for municipal landfill leachate characterization. Chemosphere, v. 251, p. 126414, 2020. Elsevier Ltd.

BAKER, A.; CURRY, M. Fluorescence of leachates from three contrasting landfills. Water Res., v. 38, n. 10, p. 2605-2613, 2004.

BRAGA, M. C. B.; AISSE, M. M.; STEINER, P. A.; DIAS, N. C; BARÉS, M. E.; TANAKA, G. T. Tratamento de lixiviados de aterro sanitário com foco na remoção de nitrogênio amoniacal, matéria orgânica biodegradável e compostos recalcitrantes: caracterização de lixiviados. São Leopoldo-RS, 2012. Partial report. 
CARSTEA, E. M. Fluorescence Spectroscopy as a Potential Tool for In-Situ Monitoring of Dissolved Organic Matter in Surface Water Systems. In: P. N. Balkis (Org.); Water Pollut. p.47-68, 2012. Intech.

CEMADEN [Internet]. São José dos Campos-SP: Centro Nacional de Monitoramento e Alertas de Desastres Naturais. Ministério da Ciência, Tecnologia, Inovações e Comunicações. Mapa interativo. 2020. Available from: http://www.cemaden.gov.br/mapainterativo/

CHRISTENSEN, T. H.; KJELDSEN, P.; HANS-JØRGEN, A.; ALBRECHTSEN, A.; HERON, G.; NIELSEN, P. H.; et al. Attenuation of Landfill Leachate Pollutants in Aquifers. Crit. Rev. Environ. Sci. Technol., v. 24, n. 2, p. 119-202, 1994.

CLARET, F.; SCHÄFER, T.; BAUER, A.; BUCKAU, G. Generation of humic and fulvic acid from Callovo-Oxfordian clay under high alkaline conditions. Sci Total Environ., v. 317, n. 1-3, p. 189-200, 2003.

COBLE, P. G. Characterization of marine and terrestrial DOM in seawater using excitation-emission matrix spectroscopy. Mar. Chem., v. 51, p. 325-346, 1996.

DIAS, N. C. Adsorção de Nitrogênio Amoniacal de Lixiviado de Aterro Sanitário em Coluna de Leito Fixo com Vermiculita Expandida [dissertation]. Curitiba: Departamento de Hidráulica e Saneamento/UFPR; 2013. 79 p.

EL-FADEL, M.; E.BOU-ZEID; W.CHAHINE; B.ALAYLI. Temporal variation of lecheate quality from pre-sorted and baled municipal solid waste with high organic and moisture content. Waste Manag., v. 22, n. 1, p. 269-282, 2002.

FARQUHAR, G. J. Leachate: production and characterization. Can. J. Civ. Eng., v. 16, n. 3, p. 317-325, 1989.

FERREIRA, P. A. S. Remoção de Nitrogênio Amoniacal de Lixiviado de Aterro Sanitário por Processos de Adsorção [thesis]. Curitiba: Departamento de Hidráulica e Saneamento/UFPR; 2014. 145 p.

GU, Z.; CHEN, W.; LI, Q.; WANG, Y.; WU, C.; ZHANG, A. Degradation of recalcitrant organics in landfill concentrated leachate by a microwave-activated peroxydisulfate process. RSC Adv., v. 8, n. 57, p. 32461-32469, 2018. Royal Society of Chemistry.

HUDSON, N.; BAKER, A.; REYNOLDS, D. Fluorescence Analysis of Dissolved Organic Matter in Natural, Waste and Polluted Waters - A Review. River Res. Appl., v. 23, p. 631649, 2007. 
HUGUET, A.; VACHER, L.; RELEXANS, S.; SAUBUSSE, S.; FROIDEFOND, J. M.; PARLANTI, E.Properties of fluorescent dissolved organic matter in the Gironde Estuary. Org. Geochem., v. 40, n. 6, p. 706-719, 2009. Elsevier Ltd.

HUO, S.; XI, B.; YU, H.; LIU, H. Dissolved organic matter in leachate from different treatment processes. Water Environ. J., v. 23, n. 1, p. 15-22, 2009.

KANG, K.; SHIN, H. S.; PARK, H. Characterization of humic substances present in landfill leachates with different landfill ages and its implications. Water Res., v. 36, p. 40234032, 2002.

KJELDSEN, P.; BARLAZ, M. A.; ROOKER, A. P.; BAUN, A.; LEDIN, A.; CHRISTENSEN, T. H. Present and long-term composition of MSW landfill leachate: A review. Crit. Rev. Environ. Sci. Technol., v. 32, n. 4, p. 297-336, 2002.

KOZAK, C.; LEITHOLD, J.; DE AZEVEDO, J. C. R.; FERNANDES, C. V. S. FEEMC 2.0. Unregistred Computer Program, 2017.

LABANOWSKI, J.; PALLIER, V.; FEUILLADE-CATHALIFAUD, G. Study of organic matter during coagulation and electrocoagulation processes: Application to a stabilized landfill leachate. J. Hazard. Mater., v. 179, n. 1-3, p. 166-172, 2010. Elsevier B.V.

LANGE, L. C.; AMARAL, M. C. S. DO. Geração e Características do Lixiviado. In: Gomes, L. P, coord. Resíduos Sólidos: Estudos de Caracterização e Tratabilidade de Lixiviados de Aterros Sanitários para as Condições Brasileiras. p.360, 2009. Rio de Janeiro - RJ: Editora ABES - Prosab 5.

LEITHOLD, J. Variabilidade Espacial E Temporal Da Matéria Orgânica No Ecossistema Aquático Nas Bacias Hidrográficas Do Alto E Médio Iguaçu. [dissertationn]. Curitiba: Departamento de Hidráulica e Saneamento/UFPR; 2017. 179 p.

LI, P.; HUR, J. Utilization of UV-Vis spectroscopy and related data analyses for dissolved organic matter (DOM) studies: A review, Crit. Rev. Environ. Sci. Technol. 47:131-154, 2017.

LIMA, L. S. M. S.; ALMEIDA, R. DE; QUINTAES, B. R.; BILA, D. M.; CAMPOS, J. C. Evaluation of humic substances removal from leachates originating from solid waste landfills in Rio de Janeiro State, Brazil. J. Environ. Sci. Heal., Part A, v. 52, n. 9, p. 828-836, 2017. Taylor \& Francis.

DE MORAIS, J. L.; ZAMORA, P. P. Use of advanced oxidation processes to improve the biodegradability of mature landfill leachates. J. Hazard. Mater., v. 123, n. 1-3, p. 181186, 2005. 
$\mathrm{OHNO}, \mathrm{T}$. Fluorescence inner-filtering correction for determining the humification index of dissolved organic matter. Environ. Sci. Technol., v. 36, n. 4, p. 742-746, 2002.

OLOIBIRI, V.; UFOMBA, I.; CHYS, M.; AUDENAERT, W.T.M.; DEMEESTERE, K.; VAN HULLE, S.W.H.A comparative study on the efficiency of ozonation and coagulation - flocculation as pretreatment to activated carbon adsorption of biologically stabilized landfill leachate. Waste Manag., v. 43, p. 335-342, 2015. Elsevier Ltd.

PACHECO, J. R.; ZAMORA, P. G. P. Integração de Processos Físico-Químicos e Oxidativos Avançados para Remediação de Percolado de Aterro Sanitário (Chorume). Eng. Sanit e Ambient., v. 9, p. 306-311, 2004.

PEDRO-CEDILLO, L. S.; MÉNDEZ-NOVELO, R. I.; ROJAS-VALENCIA, M. N.; BARCELÓQUINTAL, M.; CASTILLO-BORGES, E.R.; SAURI-RIANCHO, M.R.; et al. Evaluation of Adsorption and Fenton-Adsorption Processes for Landfill Leachate Treatment. Rev. Mex. Ing. Química, v. 14, n. 3, p. 23-43, 2015.

PEIXOTO, A. L. DE C.; SALAZAR, R. F. DOS S.; BARBOZA, J. C. DE S.; FILHO, H. J. I. Characterization of controlled landfill lecheate from the city of Guaratinguetá - SP, Brazil. Rev. Ambient. e Água, v. 13, n. 2, 2018.

PEURAVUORI, J.; PIHLAJA, K. Molecular size distribution and spectroscopic properties of aquatic humic substances. Anal. Chim. Acta, v. 337, n. 2, p. 133-149, 1997.

REN, X.; LIU, D.; CHEN, W.; JIANG, G.; WU, Z.; SONG, K. Investigation of the characteristics of concentrated leachate from six municipal solid waste incineration power plants in China. RSC Adv., v. 8, n. 24, p. 13159-13166, 2018. Royal Society of Chemistry.

ROCHA, M. C. V. DA. Digestão Anaeróbia De Lixiviado De Aterro Sanitário: Avaliação do Bioaumento da Microbiota Autoimobilizada [dissertationn]. Curitiba: Departamento de Hidráulica e Saneamento/UFPR; 2011. 123 p.

RODRIGUES, F. S. F.; BILA, D. M.; CAMPOS, J. C.; SANT'ANNA JR., G. L.; DEZOTTI, M. Sequential treatment of an old-landfill leachate. Int. J. Environ. Waste Manag., v. 4, n. 3/4, p. 445-456, 2009.

ROSTAN, J. C.; CELLOT, B. On the use of UV spectrophotometry to assess dissolved organic carbon origin variations in the Upper Rhône River. Aquat. Sci., v. 57, n. 1, p. 7080, 1995.

SHENG, G. P.; ZHANG, M. L.; YU, H. Q. A rapid quantitative method for humic substances determination in natural waters. Anal. Chim. Acta, v. 592, n. 2, p. 162-167, 2007.

SKOOG; WEST; HOLLER; CROUCH. Introdução aos métodos espectroquímicos. In: E. Thomson (Org.); Fundamentos de Química Analítica. 8ª Edição ed., p.670-703, 2005. 
VON SPERLING, M. Introdução á Qualidade das Águas e ao Tratamento de Esgotos. $3^{\text {a }}$ ed. Belo Horizonte: Departamento de Engenharia Sanitária e Ambiental, Universidade Federal de Minas Gerais, 2005.

TONG, H.; YIN, K.; GE, L.; GIANNIS, A.; CHUAN, V.W.L.;WANG, J. Y. Monitoring transitory profiles of leachate humic substances in landfill aeration reactors in mesophilic and thermophilic conditions. J. Hazar. Mater., v. 287, p. 342-348, 2015. Elsevier B.V.

WEISHAAR, J. L.; AIKEN, G. R.; BERGAMASCHI, B. A.; FRAM, M. S.; FUJII, R.; MOPPER, K. Evaluation of specific ultraviolet absorbance as an indicator of the chemical composition and reactivity of dissolved organic carbon. Environ. Sci. Technol., v. 37, n. 20, p. 4702-4708, 2003.

WESTERHOFF, P.; ANNING, D. Concentrations and characteristics of organic carbon in surface water in Arizona: Influence of urbanization. J. Hydrol., v. 236, n. 3-4, p. 202-222, 2000.

XIAOLI, C.; SHIMAOKA, T.; QIANG, G.; YOUCAI, Z. Characterization of humic and fulvic acids extracted from landfill by elemental composition, 13C CP/MAS NMR and TMAHPy-GC/MS. Waste Manag., v. 28, n. 5, p. 896-903, 2008.

XIAOLI, C.; YONGXIA, H.; GUIXIANG, L.; XIN, Z.; YOUCAI, Z. Spectroscopic studies of the effect of aerobic conditions on the chemical characteristics of humic acid in landfill leachate and its implication for the environment. Chemosphere, v. 91, n. 7, p. 10581063, 2013. Elsevier Ltd.

XIE, Z.; GUAN, W. Research on Fluorescence Spectroscopy Characteristics of Dissolved Organic Matter of Landfill Leachate in the Rear Part of Three Gorges Reservoir. J. Spectrosc., v. 2015, 2015.

YUNUS, A.; SMALLMAN, D. J.; STRINGFELLOW, A.; BEAVEN, R.; POWRIE, W. Leachate dissolved organic matter characterization using spectroscopic methods. J. Water Reuse Desalin., v. 1, n. 2, p. 78, 2011.

ZOUBOULIS, A. I.; CHAI, X. L.; KATSOYIANNIS, I. A. The application of bioflocculant for the removal of humic acids from stabilized landfill leachates. J. Environ. Manage., v. 70, n. 1, p. 35-41, 2004. 